\title{
Constructing cultural borders: depictions of Muslim refugees in British and German media
}

\author{
Tobias Müller
}

Published online: 11 December 2017

(C) The Author(s) 2017. This article is an open access publication.

\begin{abstract}
The recent migration of refugees from Muslim majority countries to Central Europe has prompted an almost unprecedented dynamic in the British and German public sphere and political culture. However, there exists a lack of understanding how the "refugee crisis" and Islam are linked to each other in public discourse. This paper addresses this lacuna by seeking to answer the question how the current refugee situation has been interpreted with regards to Islam in British and German newspapers. A critical analysis allows to identify three major discursive patterns that contribute to the securitisation of the refugee situation. Moreover, the study reveals the construction of Muslim refugees as the culturally inferior "other" to an exclusive "European Christian Culture".
\end{abstract}

Keywords Refugees · Islam · Refugee crisis · UK · Germany · Media

\section{Konstruktionen kultureller Grenzen: Darstellungen muslimischer Flüchtlinge in britischen und deutschen Medien}

Zusammenfassung Die derzeitige Migration von Flüchtlingen aus mehrheitlich muslimischen Ländern nach Mitteleuropa hat eine nahezu einzigartige Dynamik in der britischen und deutschen Öffentlichkeit und politischen Kultur in Gang gebracht. Allerdings ist bislang unzureichend erforscht, wie im öffentlichen Diskurs „Flüchtlingskrise“ und Islam miteinander in Verbindung gebracht werden. Diese Forschungslücke wird bearbeitet, indem der Frage nachgegangen wird, wie die aktuelle Flüchtlingssituation in Bezug auf den Islam von britischen und deutschen Tageszeitungen interpretiert wird. In einer kritischen Analyse werden drei diskursive Pattern

\footnotetext{
T. Müller $(\bowtie)$

Department of Politics and International Studies, University of Cambridge, Alison Richard Building, 7 West Road, Cambridge, CB3 9DT, UK

E-Mail: tm498@cam.ac.uk
} 
aufgezeigt, welche zur Versicherheitlichung der Flüchtlingssituation beitragen. Darüber hinaus zeigt die vorliegende Studie auf, wie muslimische Flüchtlinge als kulturell minderwertige „Andere“ gegenüber einer exklusiven „europäischen christlichen Kultur" konstruiert werden.

Schlüsselwörter Flüchtlinge · Islam · Flüchtlingskrise · Großbritannien · Deutschland · Medien

\section{Introduction}

The recent migration of refugees from Muslim majority countries to Western and Central Europe has prompted an almost unprecedented dynamic in the British and German public sphere and political culture. Contemporary phenomena such as the rise of right-wing and anti-Islamic movements, struggles about national identities, terrorist attacks, attacks on refugee shelters, and changing asylum laws are linked to significant developments of political culture in Europe. Especially the role of Islam has been at the centre of political debates and election campaigns in both countries. However, scholarly understanding of how the current refugee situation and Islam are linked to each other in public discourse is insufficient. There exists a dearth of studies that analyse how politicians and the media interpret the current refugee situation with regards to the interdependence of migration, Islam, and security.

This paper addresses this lacuna by analysing British and German newspaper coverage on how the topics of "refugees" and "Islam" are connected. Thereby, it seeks to answer the following research question: How has the current refugee situation been interpreted with regards to Islam in British and German media?

In order to draw representative inferences about changes in political cultures caused by the recent events, scholars need to conduct large- $n$ attitudinal studies (Pickel and Pickel 2006, p. 24). However, there still exists a dearth in data sets that can be used to test theoretical models on attitudes towards Islam and refugees (Pickel and Yendell 2016, p. 277). Attitudes towards component parts of the political system such as structures, roles, incumbents of these roles and policies are only in a few cases shaped by direct personal experiences. More often, changes in attitudes towards certain events are influenced by opinions expressed in mediated form. In particular media discourses play a crucial role in shaping people's attitudes toward political actors and structures in relation to refugees and Islam (Baker et al. 2013; Mythen 2012). Therefore, this paper seeks to investigate dominant discursive patterns in the media linking the recent refugee situation to Islam. Thus, this paper engages with the comparative literature on depictions of Muslims in the public sphere. Scholars have argued that Muslims have been constructed as "suspect communities" in the UK, parallel to Irish communities from the 1970s throughout the 1990s (Nickels et al. 2012; Pantazis and Pemberton 2009; against this Greer 2010, p. 1186).

Since the 1997 Runnymede Report, research on Islamophobia has sought to explain negative attitudes towards Muslims and Islam by testing intergroup contact theory, socialization theory, social identity theory, and integrated threat theory, among others (Dekker and van der Noll 2012, p. 113). From the perspective of parasocial 
contact theory, it is of pivotal importance to study "indirect" contacts to Muslims such as those established through the consumption of mass media. According to Pickel and Yendell, mediated parasocial contacts have contributed to an increased threat perception related to Islam (2016, p. 299). They claim that micro-level mechanisms, such as media representations that connect Islam with conflict, violence and anti-modernism, can have macro effects on political culture. At the same time, they point out the lack of research scrutinizing the relation between culturally and historically configured identities and contemporary socio-psychological processes of labelling foreign groups (cf. Bleich and Maxwell 2012, p. 44). Helbling highlights the need of qualitative research to investigate how and to what extend negative attitudes towards Muslims, Arabs, and refugees are linked (2012, p. 8). This paper addresses this lacuna by conducting a qualitative comparative analysis on how media representations portray the connection between Islam and refugees. The paper will outline micro-level mechanisms that are related mainly to three major discursive patterns. Through them, Muslim refugees are pitted against a Christian European identity (3.1.), depicted as culturally radically different, self-responsible victims that pose a security threat (3.2.) and that are responsible for the rise of far-right parties (3.3.).

\section{Research design}

This paper conducts a critical analysis of mainstream newspaper articles in order to understand how refugees in relation to Islam are being depicted. A lot of recent scholarship has focused on the effects of social media use on political culture and behaviour. However, newspapers as one of the oldest forms of political communication have retained strong influence in the political life of contemporary democracies. Many newspapers manage to establish strong relationships of identity between paper and reader that are reinforced "through various interpellations of the reading community ("our readers") and opportunities for feedback and comment" (Richardson et al. 2013 , p. 46). In particular, online publications of the same or similar content that appear under the same brand expand the accessibility of news material to a broader audience, including international readers. Scholars have argued for the persistence of the influence of newspapers on political attitudes and voting patterns: "even short exposure to a daily newspaper appears to influence voting behavior and may affect turnout" (Gerber et al. 2009, p. 47). This suggests that despite the rising influence of digital media, the analysis of newspapers promises insights into a medium that is central in shaping political orientations (Baker et al. 2013, p. 254).

The term "political culture" refers to the "specifically political orientations-attitudes towards the political system and its various parts" (Almond and Verba 1989, p. 12). The component parts of the political system are identified by Almond and Verba as roles and structures (e.g. legislative structures, executives), incumbents of such roles, and public policies, decisions and enforcements (Almond and Verba 1989, p. 14). The types of political orientation towards these elements of the political system are cognitive, comprising the knowledge of and belief about the political system, affective, meaning the personal feelings about the political system and its 
roles, and evaluational, implying the judgements and opinions about political objects (Almond and Verba 1989, p. 14). This paper uses the three dimensions of cognitive, affective and evaluational political orientation derived from the concept of political culture as analytical dimensions for the analysis of the primary data.

The present hermeneutical approach seeks to understand how texts are indicative of certain discursive sociocultural practices (cf. Fairclough 1995, p. 7). In a double movement, "the discursive event is shaped by situations, institutions and social structures, but it also shapes them" (Fairclough and Wodak 1997, p. 258). In the present analysis of political culture, texts and their inherent interpretations of the situation are analysed in terms of the arguments aiming to legitimise or deligitimise a certain political behavior (Schwab-Trapp 2003, p. 172). This analysis does not establish representativity and cannot be used to control certain factors while varying others (Schwartz-Shea and Yanow 2012, p. 70). Rather, it seeks to spell out core aspects of publicly visible and recognised communication for the construction of collective identities and social relations (Barbehön et al. 2015, p. 240). Thus, the study seeks to discern dominant discursive patterns used to make sense of the refugee situation. Limits of this kind of textual analysis include the neglect of the production processes of the texts and the perceptions by the audience (Fairclough 2003, p. 15).

The corpus of the analysis is formed by all newspaper articles in two one-week periods ( $31^{\text {st }}$ of August to $6^{\text {th }}$ September in 2015 and 2016 respectively) that contain keywords relating "refugees" and "Islam". The four newspapers selected, Die Welt, Süddeutsche Zeitung, The Daily Telegraph, and The Guardian, are among the most read and influential quality newspapers in Germany and the UK (Duffy and Rowden 2005, p. 30). The rationale behind choosing broadsheet instead of tabloid newspapers for the analysis is that this selection represents the less obvious and harder case. Arguably, the association of refugees with Islam through implicit presuppositions and suggestive causal claims is much more likely to be found in the tabloid press. However, the analysis of broadsheet newspapers that are expected to be generally more sympathetic to refugees is likely to uncover more subtle and hidden assumptions that might indicate effects of problematic power/knowledge formations. Choosing two newspapers with more conservative (Die Welt, The Daily Telegraph) and more left-leaning editorial policies (SZ, Guardian) from two countries allows to uncover patterns differing by national context and political orientation.

The first time period, from the $31^{\text {st }}$ of August to the $6^{\text {th }}$ of September 2015, was chosen because of a series of decisive events with regards to the refugee situation in Europe. First, in the annual summer press conference on $31^{\text {st }}$ of August 2015 chancellor Merkel coined the contentious phrase "Wir schaffen das", "we can do this", which has later been called the most important sentence of her time in office (WeltN24 2016). The context of this statement consists of the almost unprecedented increase in incoming refugees, mainly being brought by buses and special trains from Hungary via Austria to Germany. Moreover, the image of the dead body of Aylan Kurdi, a Syrian boy of three years who was found at a beach in Turkey near Bodrum on September $2^{\text {nd }}$, aroused international attention and reactions by leading politicians. Finally, the chosen period witnessed fierce debates between European heads of state regarding a possible distribution mechanism among EU member states. The second time period under scrutiny is from $31^{\text {st }}$ August to $6^{\text {th }}$ September 2016, 
Table 1 Result of keyword searches and corpus selection

\begin{tabular}{lllll}
\hline & $\begin{array}{l}31 / 8-6 / 9 / 2015 \\
\text { Keyword } \\
\text { search }\end{array}$ & $\begin{array}{l}\text { Selected for final } \\
\text { corpus }\end{array}$ & $\begin{array}{l}\text { 31/8-6/9/2016 } \\
\text { Keyword } \\
\text { search }\end{array}$ & $\begin{array}{l}\text { Selected for final } \\
\text { corpus }\end{array}$ \\
\hline Welt & 12 & 7 & 18 & 13 \\
SZ & 42 & 21 & 33 & 19 \\
Telegraph & 9 & 3 & 14 & 6 \\
Guardian & 137 & 12 & 27 & 8 \\
Total & 200 & 43 & 92 & 46 \\
\hline
\end{tabular}

exactly one year after the first one. Choosing this time period allows a diachronic comparison that reflects how media discourse has changed over the course of a year. Significant events in that year include the terrorist attacks in Paris, Brussels, Nice, Würzburg and Ansbach, the attacks in Cologne on New Year's Eve, and the Brexit vote on $23^{\text {rd }}$ of June 2016. Many articles in the second time period have critically discussed the "Wir schaffen das" statement by Merkel using the opportunity of the anniversary to reflect on the refugee situation, which is typically particularly urgent in the summer months.

The corpus was built through keyword search in LexisNexis and the SZ digital archive. Articles were included if they contained both a keyword referring to Islam such as "Islam", "Muslim", "headscarf", "hijab" and a keyword referring to refugees such as "refugee", "migrant", "migrat", or "asyl". A second search included the terms "extremist" and "communit" in combination with the keywords on refugees in order to account for indirect modes of speaking about Muslims, especially in the UK context. After gathering the large corpus with a total of 292 articles, those articles that did not relate to the European "refugee crisis", were removed from the sample. As a result, the final corpus comprised 89 articles with a total of around 83,000 words as indicated in Table 1 .

\section{Portraying refugees as Muslims in British and German media}

In the following, the research question on the depiction of refugees as Muslims is addressed by outlining three major discursive strands that were uncovered in the media analysis: the construction of a "Christian European Culture" (3.1.), the construction of cultural difference, self-responsible victims and a security threat (3.2.), and attributions of responsibility linking chancellor Merkel, Muslim refugees and the rise of the far-right (3.3.).

\subsection{Constructing a "Christian European culture"}

As indicated above, the search entries for the selection of the articles comprised only keywords that were directly related to Islam. Although "Christianity" was not part of the original search mask, it turned out that depictions of the refugee crisis were predominantly made against the background of a purported Christian or "Judeo- 
Christian" European identity (Kade 2016). For instance, the argumentative structure of the Hungarian Prime Minister Orbán arguing against accepting more refugees is built on the construction of a sharp differentiation between the religious identity of refugees and of the current Hungarian and European population. He claims that "those arriving have been raised in another religion and represent a radically different culture. Most of them are not Christians, but Muslims. [...] Is it not worrying in itself that European Christianity is now barely able to keep Europe Christian?" (Traynor 2015a; Bergmer 2015). This rhetorical question refers to an implicit assumption that Europe is and even should remain Christian. Building on this assumption, Orbán stylises himself in militaristic language as having to "defend our borders," to defend "European Christianity" against the "offensive" of the "Muslim influx" (Traynor 2015b).

An integral part of what can be called a Christians-as-insiders and Muslimsas-outsiders rhetoric is the underlying assumption that certain countries were dominated by one religion. Therefore, some articles suggest that it was normal or common sense to try to keep out people that do not share the same religion: "Hungarians did not want Muslims in their country" (Traynor 2015a). Some articles even attribute responsibility for accepting refugees to countries that share the same religion or even the same confession: "Sunni countries, headed by Saudi Arabia, should take in Sunni refugees. Shia countries, headed by Iran, should take Shia refugees. Christian countries should then take Christian refugees." (Sherborne 2015; cf. Steinke 2015). This statement implies that it was more natural and beneficial if different religious groups remained separated. This reveals an ideal of religious homogeneity underlying the text which implies that a human right such as asylum should be granted not according to need but according to religious affiliation. Arguing for such discriminatory measures including watering down human rights standards by invoking Christianity appears paradoxical in face of the proclaimed "Christian" values such as liberal democracy and "dignity of every human being" (Esslinger und Steinke 2016). ${ }^{1}$ Statements by senior German Christian democratic politicians reveal the same referential mechanism that fails to specify what a Christian identity of Europe means: "I am not of the opinion that Islam is part of the national identity of our country. The Muslims living in Germany belong to us, they are part of our society. But we have a Christian-Jewish tradition" (Kade 2016).

Another senior Christian democratic politician claims that the challenge to accept refugees is now bigger compared to refugees coming from a country with Christian tradition. Asked why this is the case, she answers that "The origin and the way of life a human being lives in his homeland shape him. This is completely normal. Like we Germans are shaped by the rule of law, the basic law, our civil and personal liberties and Christianity" (Esslinger und Steinke 2016). In this statement, a discursive pattern of what could be called implication by correlation becomes visible, which occurs on multiple occasions throughout the texts. The conservative politician responds to the question about why it should be more challenging to integrate nonChristian immigrants by naming generally positively evaluated concepts as part of German identity. By implication, this suggests that non-Christians-the context of

\footnotetext{
1 All quotations from German newspapers have been translated by the author.
} 
the interview reveals that she is talking about Muslims-are not "shaped by" or as intimately familiar with these concepts. Pushed even further by the interviewer to define what "Christian influence" actually means, she answers "Love of neighbour, tolerance. The values that my parents have taught me, with respecting the dignity of every human being, which ultimately also expresses itself in our constitution" (Esslinger und Steinke 2016). The claims that German identity and Christian culture mainly express themselves in the constitution expose a political theology that is at least in tension with the self-proclaimed religious neutrality of the constitutional state.

In the articles under scrutiny "Christianity" is largely stripped of a genuinely religious meaning and used to signify an indefinite set of concepts and structures that are an integral part of political culture. This change in signification helps to construct the cultural container "Christianity" and a culturally and religiously defined border to the "other". Thus, because refugees do not share this religious tradition, they also purportedly do not share the support for core principles of liberal democracy. In other words, "Christianity" serves to proof that human dignity, rule of law and civil liberties are unfamiliar or even alien concepts to Muslim refugees. Through this rhetoric, talking about a "refugee influx" into Europe becomes inextricably linked not only to crossing borders of nation states but to crossing the cultural border between "Christian liberal democracy" and the "rest". In the argumentation quoted above, a confined territoriality ("homeland") is connected with an exclusive community of belonging ("we Germans" and "Christians"), and is linked with cultural superiority ("rule of law" and "our civil and personal liberties"). This tripartite amalgamation can be interpreted as the epitome of the discursive construction of the Muslim refugee as the "Other". In sum, two seemingly clear cut cultural-spatial containers are being constructed that are marked by a sharp distinction between a "European Christian Culture" "here" and a "Muslim Culture" "there". This spatio-cultural construction provides the discursive basis for arguments claiming that the integration of Muslims was especially difficult or even impossible.

\subsection{Depicting refugees: cultural difference, self-responsible victims and security threat}

Muslim refugees are not only considered to be unfamiliar with tolerance and principles of liberal democracy but also conceived as culturally "completely different" (Braun and Roll 2016) because "The hundred thousands of Muslims, that are coming now" (Belkin 2016) are from a "radically different culture" (Traynor et al. 2015). One author claims "that who comes has to accept the rules here, the liberties and cultural codes. Who comes here a thousand kilometers by foot has to cover the same distance in his head" (Rühle 2016). This statement suggests that the often very dangerous journey to Europe is as big a challenge for Muslim refugees as to bridge the gap of cultural differences.

While Muslim refugees are depicted as unfamiliar with and often not willing to accept the rules and cultural codes of the host society, one author contends that "Germany has a long tradition of knowing the Orient" (Krause 2016). He claims that because Muslim people "destroy each other or are being alienated by primitive 
and criminal Islamists from their best traditions, [...] we Germans actually have to reinforce the self-consciousness of those that fled to us. Namely by reminding them of their cultural achievements" (Krause 2016). While on an evaluational level this article positively acknowledges some elements of Muslim culture, it asserts that it is up to Germans knowing the Orient to remind Muslims of the positive sides of their heritage. While on a cognitive level the texts disagree fundamentally about the existence or value of "Muslim culture", the knowledge/power formation that they enact has similar effects. No matter whether Muslim refugees are considered lacking something like a positively evaluable "culture" or as just having forgotten it, both positions result in the establishment of asymmetrical power relations. Thus, Muslim refugees are constructed as passive postcolonial subjects that are dependent on the rules, norms, and codes established by culturally superior Europeans (cf. Said 1978, p. 5).

Addressing the policy dimension of political culture, one text directly translates these cultural differences into a political demand for an "immigration system that is tiered according to qualitative and cultural criteria. We should privilege well-educated refugees as well as Christians and other persecuted minorities from the Near East that usually have a higher readiness to assimilate" and "check whether they are culturally compatible with our basic values" (Wergin 2015). This implies the even more demanding cognitive assertion that it was somehow possible to form and measure "cultural criteria" that on an evaluational level should be the decisive criterion about whether refugees should be accepted or not. Therefore, not only are Christians supposedly more familiar with elements of liberal democracy and culturally more "advanced", they are also supposed to be willing to give up their cultural, national, and religious identity in order to assimilate into European societies. This, again, implies a causality between religious homogeneity, cultural similarity, and successful integration or even assimilation. The author goes even further by demanding that those refugees who come are required to have "sufficient cultural capital in order to persist in a rapidly changing economy" (Wergin 2015). Therefore, we "need [...] the right immigration" which means choosing "whom we can make use of" (Wergin 2015). This statement endorses the possibility and the desirability of categorizing refugees into "needed" and "not needed". It is therefore not only a set of cultural codes and political values, but also a set of skills related to economic performance that is constructed as requirement for refugees to be granted asylum.

In an amalgamation of economic, cultural, and religious argumentative snippets, the alleged reason for immigrants' failure to be compatible with the European economic and cultural system is that they come from "culturally backward regions around the Mediterranean" (Wergin 2015). This "double-bind" becomes evident in the statement by one author: "the refugee is a victim that, however, is self-responsible. And the people come here for good reasons and not to Pakistan or Saudi Arabia. They come here because here there are liberties, but you also have to accept them" (Rühle 2016). The self-responsible victim turns out to be the paradox figure that is torn between conflicting predications and the imperatives derived from them. On the one hand, the Muslim refugee is seen as victim of war, structural disadvantages, lack of cultural knowledge, deficient education and religious backwardness. On the other hand, the refugee is thought to have freely chosen to come to Europe. This 
purported act of free will is then used as an argument to claim that the Muslim refugee is self-responsible in overcoming all obstacles and in accepting European rules and traditions, its Christian character, and the demands of a dynamic economic system. This means that the self-responsible victim is depicted as being restricted and disadvantaged by deep-rooted, fundamental differences and "trenches", while at the same time it is equally up to her to successfully integrate according to the vision of European societies.

Along with the cognitive assessment of deficient skill sets and cultural compatibility, the words used to collectively describe refugees are often metaphors associated with force of nature or the movement of large material quantities. The wordings used in both conservative and left-leaning newspapers include "refugee wave" (Fried 2015), "stream of refugees" (Mühlfenzl 2016; Wergin 2015), "refugee flood" (Schulte von Drach 2015), "mass migration [Völkerwanderung]" (Herzinger 2015; Büscher 2015), "Muslim influx" (Traynor 2015a), and "onslaught of asylum seekers" (Wergin 2015). Using these metaphors associates the situation with several characteristics of natural forces. On the one hand, as the weather causing natural disasters, the situation is suggested to come from outside, recalling the contrast between the untamed and wild nature and the well-ordered "civilised" human society. Most narratives that include natural disasters imply that the only reasonable reaction is to build barriers between the forces of nature "outside" and that which must be protected "inside". The repeated collocation of words in dominant discursive structures make it highly unlikely that words like "flood", "wave" and "onslaught" are used to describe a group in a neutral, let alone positive way. Using a language of natural disasters is likely to contribute to a disregard of individual rights and individual needs.

Another central pattern in the depiction of Muslim refugees is the association with jihadist terrorism. The connection between Muslim refugees and terrorism is established through different narrative elements and chains of association. First, texts indirectly quote politicians warning of the so-called Islamic State smuggling "sleeping terror cells" as refugees to Europe (Brössler et al. 2015; Schulte von Drach 2015). One commentator claims that "the security agencies are now afraid that radicals hide among the refugees that stream uncontrolled into Europe. [...] One should not pretend that Europe does not have a problem with Muslim immigrants, albeit only with a minority" (Wergin 2015). The author claims that there exists a lack of control of refugees that travel to Europe. This ignores the fact that while there have been a large number of people crossing borders without being registered in transit countries, most refugees, including the attackers of Ansbach and Würzburg, were officially registered as refugees by the state. The statement furthermore implies that it was possible to simply start controlling and thereby stopping the danger of terrorists entering European countries. It remains unclear, however, where and how these controls could be implemented and how they would identify potential terrorists. Despite falling short of providing answers to these open questions, the statements help to construct the idea of an easy solution in form of the undefined concept of "control".

In addition to the construction of the "sleeping terror cell" narrative, an implicit causal link between Islam and terrorism is being established. Making use of irony 
to point out the naïveté of the opposite standpoint, a text claims that "Islam is throughout a noble and peaceful religion and culture, which is why Islamic militants have to be incited to their infamous actions by evil powers of Western degradation" (Herzinger 2015). Here, the text builds on the presupposition of the audience that Islamic militants are not incited by anything else but by Islam itself. An article by a leading British Labour politician claims that "Our security interest in tackling the refugee crisis remains powerful, too. Criminal trafficking gangs are getting stronger, extremists are able to exploit the crisis, and the disorder of an unmanaged response threatens community cohesion and stability" (Cooper 2016). This can be interpreted as a securitising speech act because a topic that is not conventionally dealt with in terms of security is now framed as a security threat (Buzan et al. 1998, pp. 23-26). By also using "community" as key word in building the corpus, it is possible to identify this implicit dual reference to Muslims in the context of the refugee crisis. Both the exploiting extremists and the threatened communities are Muslims. Moreover, both are constructed to be in need of intervention by the security apparatus: the extremists have to be persecuted, the communities have to be protected. Therefore, this cognitively constructed need of state intervention, complemented with a threat aiming at creating fear on an affective level, is translated into evaluational support for the strong security interest in the refugee crisis. Applying the Foucauldian concept of governmentality one can argue that this power/knowledge formation constructs Muslim refugees as a population that needs to be governed by apparatuses of security (Foucault 1991, p. 102; 1978; 1997).

\subsection{Attributing responsibility: Merkel, Muslim refugees and the rise of the far- right}

A third major discursive strand concerns the cognitive and evaluational dimension towards an incumbent of a political role, the German chancellor Angela Merkel. Merkel is attributed responsibility for the influx of Muslim refugees to Europe. In addition to that, the increased presence of refugees and Merkel's rhetoric are constructed as principal causes for the rise of far-right parties in Germany. In contrast to the debates around the feared loss of European Christian identity, one article hails Merkel as demonstrating "a little leadership, at last" in face of the "outrageous noises coming from some capitals about admitting only Christian, and not Muslim refugees" (Guardian 2015). Predicates and metaphors used include "Mama Merkel", "compassionate mother", the "mother of the Outcasts" and "\#Merkel_TheEthiopian" referring to a Christian ruler that is reported to have given refuge to Muslim refugees (Olterman 2015). Again, it is Merkel's alleged Christianity that is emphasised when refugees are framed as Muslims. In contrast, one author claims that Merkel's "welcoming of refugees" to the "laid table" was a "moral defeat" (Brössler et al. 2015). Blaming Merkel for attracting refugees and creating a "pull" effect featured in the articles only as quotations from nationalist, right-wing, Eastern European political leaders in September 2015. However, this has completely changed one year on. In September 2016, there has been no mentioning of any positive predicate on an affective level towards Merkel in any of the articles. To the contrary, in 2016, Merkel is mainly remembered for two interdependent things that have turned her into the 
personification of the "refugee crisis". The phrase "we can do this" from $31^{\text {st }}$ of August 2015 has come to signify a whole bundle of terms that are used to criticise government policy or to advance arguments against accepting refugees (Huggler 2016; Welt 2016).

On the other hand, the statement that "Mrs Merkel opened Germany's borders to more than a million asylum seekers" (Huggler 2016) indicates on a cognitive level that all these asylum seekers entered Germany through newly opened borders. This depiction of the situation ignores the fact that borders between most EU member states have been open since the Schengen agreement that came into force in 1995 . The article attributes agency to Merkel by implying that it was her actions that made "more than a million asylum seekers" to enter Germany. This reveals a frequent pattern throughout the discussions of Merkel, refugees and the rise of right-wing parties in Germany in 2016, namely, the assumption of the manageability of migration and especially Muslims coming to Germany.

This proposition is made even stronger in articles on the relative electoral success of the far-right party Alternative for Germany (AfD). While the rise of the far-right was not an issue mentioned in any article in 2015, the relative electoral success in the Mecklenburg-Vorpommern state election on the $4^{\text {th }}$ of September 2016 was a key concern in the articles in 2016. In this election, the AfD won $21 \%$ of the votes participating in the election for the first time. The party programme has been summarised as "openly anti-migrant and anti-Muslim" (Huggler 2016). The "recipe of success" of the AfD is characterised as attacking Merkel's refugee policies and inciting "fear especially from Muslim migrants" (Welt 2016). Moreover, it is claimed that "major attacks of the AfD were launched continuously and extensively against immigration and Islam in particular" (Kamann 2016a). Thus, one AfD politician admonishes that "our land is transformed step by step into a caliphate" (Burghardt 2016). The articles depict details of the "anti-migrant and anti-Muslim" propaganda and claim that both the rhetoric and the topics contributed to their electoral success. The larger causal link suggested in the articles is that since Merkel is responsible for the large number of refugees coming to Germany, most of which are Muslim, right-wing parties with anti-Muslim propaganda are successful.

\section{Constructing cultural borders: beyond Christian Germany and multicultural Britain}

The analysis conducted on newspapers from two countries allows to point at several differences and similarities in British and German media representations. Complementary to the three major patterns outlined above, this addresses the comparative dimension of the research question on how the refugee situation has been interpreted with regards to Islam in British and German media.

A first outcome of the comparison is that refugees and Islam are much more often discursively linked in German media. A look at the article selection along the criteria mentioned above reveals that in the first time period there were 28 articles in German, 15 in British newspapers, in the second time period 32 in German, 14 in British newspapers. This means that the refugee situation and Islam are much less 
often associated in the British than in the German press. An obvious explanation would be that a much larger number of refugees came to Germany than to the UK in this period which is why the topic was more present in the press. However, given the heated debates on migration before and after the "Brexit" vote on $23^{\text {rd }}$ June 2016, this explanation does not seem fully satisfactory. One reason could be that the debate on immigration was not only focused on refugees coming from the Middle East and North Africa, but also on EU migrant workers, mainly from Poland. In the British context, the connection between anti-migrant and anti-Muslim seems to be much less well-established than in Germany. Given the long migration history of people with different beliefs including Muslims from former colonies, in particular India, Pakistan, and Bangladesh, this seems plausible. This might also be an explanation for a second conjecture: The cultural and religious composition of the receiving society is only directly problematized in German media. This is indicated by the fact that only in the German newspapers there were comments critical of "multiculturalism" (Broder 2015; Beitzer 2016; Kamann 2016b; Pröhle 2015). Also, the cultural changes effected by more Muslim immigrants were only discussed in German media. Finally, questions like "do we really want these changes" were expressed by politicians that are not part of the far-right, but of the ruling Christian democrats. These findings suggest that at least in quality newspapers, religious and ethnic diversity per se is not contested in the UK, at least in relation to refugees. In contrast to that, in Germany the refugee situation has sparked a discussion about whether the increasing religious diversification is something that should be welcomed or prevented.

Another substantial difference lies in the culturalist rhetoric that re-constructs German national identity: The reference to a (Judeo-)Christian heritage is only used in Germany to mark the difference between Muslim refugees and the host society. It seems that the construction of the "other" in Germany is much more focused on Muslim refugees as non-Christians. Also, only in German media the "cultural compatibility" of Muslim refugees was questioned. The cognitive distinction is based on the discursive reconstruction of "Christian Europe", in particular by leading Christian democratic politicians. The more frequent occurrence of refugees as Muslims in German newspapers could also be explained by the fact that mainly conservative and far-right politicians were given the opportunity to express their opinions on the topic in Germany. In contrast to that, a leading Labour politician and a pro-immigration priest from the Church of England were among the voices talking about Muslim refugees in the British newspapers. No conservative politician featured in any article in the British news that directly addressed or implied the fact that many refugees were Muslims. An explanation could be that high awareness of racism and Islamophobia in the UK makes it less beneficial or less accepted to talk about the religious affiliation of refugees. Another reason for this could be that the group of Muslims mentioned most often in British public discourse is not refugees, but the often wellestablished communities from Commonwealth countries, in particular from South Asia.

The analysis of the data reveals that both in British and German media Muslim refugees are linked to terrorism on a cognitive and an affective level. Articles from both national contexts feature the fear of "sleeper cells" hiding among the "masses" 
of incoming refugees. Therefore, on an evaluational level, Muslim refugees are constructed as a population that needs to be governed by the state. This includes for instance the reintroduction and reinforcement of border controls and checks on the "compatibility" and "willingness to assimilate". Thus, in what can be called a process of securitisation, Muslim refugees are discussed as a security problem for Europe in the UK and Germany. The discursive patterns suggests that the "Muslim refugee problem" has to be dealt with by means of security. This requires exceptional measures that transgress the rules of regular politics such as discrimination on the basis of religious affiliation, curtailing universal human rights, and abandoning foundational international treaties. The strong connection between Muslim refugees and terrorism has been established by statements from top government officials, leading party members, journalists and ordinary citizens in both countries. Thus, the empirical evidence presented here supports both the "state version" and the "civil society version" of the "suspect community thesis" (Greer 2010, p. 1172).

The construction of a "European Culture", with an emphasis on its distinctive "Christian" character in the case of Germany, is a crucial foundation for the securitizing argumentation. In both countries, the association of the territoriality of a European, British or German "homeland" with certain cultural and political elements such as liberal democracy and rule of law constructs a socio-cultural border. In this "culture war" (Beitzer 2016), the "we", the non-Muslim Europeans-as-insiders, have to be defended against the Muslims-as-outsiders. Only by establishing these culturally and religiously defined boundaries, the exclusion of "them" that do not "fit" appears to be both feasible and desirable. The role of European societies is predominantly constructed as having to defend Christian culture and to manage and to control refugees. European societies have to intervene in Muslims communities to protect and to persecute. They must become active against "them" coming to Europe and to prevent "what happened in the summer of 2015". Muslim refugees, in turn, are constructed as subjects that are self-responsible victims and that have to assimilate into a diffuse bricolage of European history and culture. They are expected to gather economic skills so that they can be useful to the majority society. Also, they are constructed as the cause for electoral success of far-right parties.

The analysis of media representation of refugees as Muslims has highlighted the immediate salience of what Olivier Roy has called Europe's identity crisis (Roy 2013, pp. 61-65). The importance of a better understanding of this crisis and its relation to the discourse on refugees and Islam cannot be overstated given the rapid changes in public opinion in Germany and the UK. Politics emerging from the highly problematic and emotionally charged depictions of Muslim refugees have the potential to have disastrous effects for both new and well-established citizens and political cultures of both countries. It is up to further research to scrutinise to what extent the discursive patterns outlined above translate into changes in public opinion, voting behavior and legislation targeting both refugees and Muslims.

Acknowledgements I am grateful to Sybille Münch, Sebastian Scholl, two anonymous reviewers, and the participants of the workshop "Migration und Integration als politische Herausforderungen" in Leipzig, June 2016, for their helpful comments on earlier versions of this paper. 
Open Access This article is distributed under the terms of the Creative Commons Attribution 4.0 International License (http://creativecommons.org/licenses/by/4.0/), which permits unrestricted use, distribution, and reproduction in any medium, provided you give appropriate credit to the original author(s) and the source, provide a link to the Creative Commons license, and indicate if changes were made.

\section{References}

Almond, Gabriel, and Sidney Verba. 1989. The civic culture. Political attitudes and democracy in five nations. Newbury Park: SAGE.

Baker, Paul, Costas Gabrielatos, and Tony McEnery. 2013. Discourse analysis and media attitudes: The representation of Islam in the British press. Cambridge, New York: Cambridge University Press.

Barbehön, Marlon, Sybille Münch, Petra Gehring, Andreas Grossmann, Michael Haus, and Hubert Heinelt. 2015. Urban problem discourses: Understanding the distinctiveness of cities. Journal of Urban Affairs 38:236-251.

Beitzer, Hannah. 2016. Die AfD führt einen Kulturkampf. SZ, 5 Sept.

Belkin, Dimitrij. 2016. Als die Russen kamen. Die Welt, 3 Sept.

Bergmer, Alexander. 2015. Fremd im eigenen Land. SZ, 5 Sept.

Bleich, Erik, and Rashaan Maxwell. 2012. Assessing islamophobia in Britain: where do Muslims really stand? In Islamophobia in the West. Measuring and explaining individual attitudes, ed. Marc Helbling, 39-55. London: Routledge.

Braun, Stefan and Evelyn Roll. 2016. "Deutschland wird Deutschland bleiben". SZ, 31 Aug.

Broder, Henryk M. 2015. Wir lassen gebären. Die Welt, 2 Sept.

Brössler, Daniel, Florian Hassel and Thomas Kirchner. 2015. Wir müssen draußen bleiben. SZ, 1 Sept.

Burghardt, Peter. 2016. Schloss und Riege. SZ, 5 Sept.

Büscher, Wolfgang. 2015. Die Guten, die Bösen und die Ängstlichen. Die Welt, 1 Sept.

Buzan, Barry, Ole Wæver, and Jaap de Wilde. 1998. Security: A new framework for analysis. Boulder, London: Lynne Rienner.

Cooper, Yvette. 2016. A year on from Alan Kurdi. The Guardian, 2 Sept.

Dekker, Henk, and Jolanda van der Noll. 2012. Islamophobia and its explanation. In Islamophobia in the West. Measuring and explaining individual attitudes, ed. Marc Helbling, 112-123. London, New York: Routledge.

Duffy, Bobby, and Laura Rowden. 2005. You are what you read? How newspaper readership is related to views. London: MORI. https://www.ipsos-mori.com/DownloadPublication/240. Accessed 1 Oct 2016.

Esslinger, Detlef and Ronen Steinke. 2016. Neue Heimat, alte Heimat. SZ, 2 Sept.

Fairclough, Norman. 1995. Critical discourse analysis: The critical study of language. London: Longman. Fairclough, Norman. 2003. Analysing discourse: Textual analysis for social research. London: Routledge.

Fairclough, Norman, and Ruth Wodak. 1997. Critical Discourse Analysis. In Discourse as Social Interaction, ed. Teun van Dijk, 258-284. London: SAGE.

Foucault, Michel. 1978. An introduction. The history of sexuality, Vol. I. New York: Pantheon Books.

Foucault, Michel. 1991. Governmentality. In The Foucault effect, ed. Graham Burchell, Colin Gordon, and Peter Miller, 87-104. Chicago: University of Chicago Press.

Foucault, Michel. 1997. What is critique? In What is enlightenment? Eighteenth-century questions and twentieth-century answers, ed. James Schmidt, 382-399. Berkeley: University of California Press.

Fried, Nico. 2015. In einem anderen Land. SZ, 1 Sept.

Gerber, Alan S., Dean Karlan, and Daniel Bergan. 2009. Does the media matter? A field experiment measuring the effect of newspapers on voting behavior and political opinions. American Economic Journal: Applied Economics 1:35-52.

Greer, Steven. 2010. Anti-terrorist laws and the United Kingdom's suspect Muslim community: A reply to Pantazis and Pemberton. British Journal of Criminology 50:1171-1190.

Guardian. 2015. The Guardian view on Europe's refugee crisis. 1 Sept.

Helbling, Marc. 2012. Islamophobia in the West: An introduction. In Islamophobia in the West. Measuring and explaining individual attitudes, ed. Marc Helbling, 1-18. London: Routledge.

Herzinger, Richard. 2015. Schuld ist immer der Westen? Die Welt, 31 Aug.

Huggler, Justin. 2016. Merkel suffers serious setback. The Daily Telegraph, 5 Sept.

Kade, Claudia. 2016. "Viele fühlen sich politisch heimatlos". Die Welt, 6 Sept.

Kamann, Matthias. 2016a. Nicht regieren müssen. Die Welt, 5 Sept.

Kamann, Matthias. 2016b. Das sind die Neuen von der AFD. Die Welt, 6 Sept. 
Krause, Tilman. 2016. Deutsche waren immer Islamversteher. Die Welt, 3 Sept.

Mühlfenzl, Martin. 2016. Ernüchterung im Bierzelt. SZ, 6 Sept.

Mythen, Gabe. 2012. 'No one speaks for us': security policy, suspected communities and the problem of voice. Critical Studies on Terrorism 5:409-424.

Nickels, Henri C., Lyn Thomas, Mary J. Hickman, and Sara Silvestri. 2012. De/constructing 'suspect' communities. Journalism Studies 13:340-355.

Oltermann, Philip. 2015. Mama Merkel. The Guardian, 2 Sept.

Pantazis, Christina, and Simon Pemberton. 2009. From the 'old' to the 'new' suspect community. Examining the impacts of recent UK counter-terrorism legislation. British Journal of Criminology 49:646-666.

Pickel, Gert, and Alexander Yendell. 2016. Islam als Bedrohung? Beschreibung und Erklärung von Einstellungen zum Islam im Ländervergleich. Zeitschrift für Vergleichende Politikwissenschaft 10:273-309.

Pickel, Susanne, and Gert Pickel. 2006. Politische Kultur- und Demokratieforschung. Wiesbaden: VS.

Pröhle, Gergeley. 2015. Das ist ein bisschen wie beim Mauerfall. SZ, 2 Sept.

Richardson, Kay, Katy Parry, and John Corner. 2013. Political culture and media genre: Beyond the news. Basingstoke: Palgrave Macmillan.

Roy, Olivier. 2013. Holy ignorance: When religion and culture part ways. Oxford: Oxford University Press.

Rühle, Alex. 2016. Lob des Zweifels. SZ, 2 Sept.

Said, Edward W. 1978. Orientalism. London: Penguin Books.

Schulte von Drach, Markus C. 2015. Wie Menschen zu Brandstiftern werden. SZ, 2 Sept.

Schwab-Trapp, Michael. 2003. Methodische Aspekte der Diskursanalyse. Probleme der Analyse diskursiver Auseinandersetzungen am Beispiel der deutschen Diskussion über den Kosovokrieg. In Forschungspraxis Handbuch Sozialwissenschaftliche Diskursanalyse, Vol. II, ed. Reiner Keller, Andreas Hirseland, Werner Schneider, and Willy Viehöver, 169-196. Opladen: Leske + Budrich.

Schwartz-Shea, Peregrine, and Dvora Yanow. 2012. Interpretive research design: Concepts and processes. New York: Routledge.

Sherborne, Alan E. 2015. Britain should not be bound by the EU's chaotic approach to migration. The Daily Telegraph, 3 Sept.

Steinke, Ronen. 2015. Die Angst der Araber. SZ, 5 Sept.

Traynor, Ian. 2015a. Migration crisis. The Guardian, 3 Sept.

Traynor, Ian. 2015b. Europe set for bruising battle over sharing refugee burden. The Guardian, 4 Sept.

Traynor, Ian, Kim Willsher and Sabrina Siddiqi. 2015. Germany presses Europe into sharing refugees. The Guardian, 4 Sept.

Welt. 2016. AfD würde in Schwerin mit der NPD stimmen. 1 Sept.

WeltN24. 2016. Merkel sieht "Wir schaffen das" kritisch. 19 September. https://www.welt.de/politik/ deutschland/article158211662/Merkel-sieht-Wir-schaffen-das-kritisch.html. Accessed 1 Oct 2016.

Wergin, Clemens. 2015. Einwanderung, zweiter Versuch. Die Welt, 5 Sept. 